\title{
AWARENESS OF SECOND LANGUAGE INFLECTIONAL MORPHOLOGY: A CASE STUDY ON FINNISH AS A SECOND LANGUAGE
}

\author{
MINNA SUNI \\ Department of Languages \\ University of Jyväskylä \\ P.O. Box 35 \\ FIN-40014 Jyväskylä \\ Finland \\ minna.suni@jyu.fi
}

\begin{abstract}
The Finnish language has a very extensive inflectional morphology, whereas Vietnamese, as an isolating language, has no inflection at all. Therefore, the major challenge encountered by Vietnamese immigrants learning Finnish is to develop awareness of the existence, function and use of inflection. This paper examines how this process manifests itself in native-non-native speaker (NS-NNS) conversations during the initial stages of second language acquisition. All the negotiation sequences including overt signals of problems in understanding were subjected to a closer analysis, and the linguistic modifications performed to solve the problems were analysed on the level of both interaction and grammar. In this paper, the focus is on the observable signs of gradually growing morphological awareness, and especially the receptive segmenting skills of the learners.
\end{abstract}

Keywords: second language acquisition, negotiation of meaning, recast, morphology, Finnish

\section{Introduction}

In the field of interactionally oriented second language acquisition research, such related topics as the negotiation of meaning and modified interaction have recently gained a lot of attention. This branch of study concentrates on the circumstances that problematic interaction creates for language learning. A common starting point has been the hypothesis that the more negotiation and modification there is to be observed in interaction, the better the results are from the point of view of language 
learning. This approach is mainly based on the arguments of Long (1983; 1996) and Swain $(1985 ; 2005)$ who have emphasized the role of comprehensible input and output in the second language acquisition process.

In empirical studies dealing with modified interaction the focus has gradually shifted from the structure and frequency of negotiations of meaning in different tasks or classroom activities (e.g., Doughty-Pica 1986; Cameron-Epling 1989; Pica et al. 1993; Rulon-McCreary 1986; Yule-Macdonald 1990) to the type, number and results of linguistic modifications occurring in them (Pica et al. 2006). By promoting the noticing and awareness of new linguistic features, the recasts proposed by native speakers have also become of special concern in this field (e.g., Leeman 2003; Philip 2003; Carpenter et al. 2006).

In her comprehensive review article on negotiations of meaning, Pica $(1994,518)$ has noted that lexical items and larger syntactic units are the most obvious objects of negotiation, and that the modification of morphology is rare (see also Deen 1997; Pica et al. 2006). However, this may be a simplified view, because the target languages involved have almost exclusively been languages such as English, in which inflectional morphology plays a rather marginal role.

In this paper, the scope will be broadened to include a different linguistic setting, where learners of Finnish as a second language (L2), having Vietnamese as their first language (L1), interact with a native speaker. As an isolating language, Vietnamese is typologically very distant from Finnish, which has an extensive morphological system. The aim is to show how gradually growing morphological awareness manifests itself during a 10-week period in the early phase of second language learning.

Vietnamese was one of the first new immigrant languages that arrived in Finland in the 1980's. Teachers of Finnish L2 have described Vietnamese-speaking learners as the most demanding target group they have ever had (e.g., Suni 1996). In comparison to some other immigrant groups, they have been assessed as having the slowest rate of Finnish language acquisition, while speakers of Estonian seem to be the quickest learners because the L1 linguistic system is closely related to Finnish (Pälli-Latomaa 1997; Kaivapalu 2005; Tarnanen-Suni 2005). Instead of simply listing some obvious difficulties, it is worth observing how second language inflectional morphology is actually dealt with by speakers of an isolating language. 


\section{Data and methods}

The 5-hour data consist of native-non-native speaker (NS-NNS) conversations between two Vietnamese learners of Finnish and a native speaker. Both learners were newly arrived adult immigrants (worker males, aged 22 and 36) with Vietnamese as L1. Having lived in multilingual environments, they also knew some Chinese or Cambodian, and Thai. They had an elementary knowledge of English but no prior knowledge of Finnish on arrival in Finland. The NS had only little experience of talking with NNSs.

The conversations could be described as informal, and they took place in the NNSs' homes without interrupting their normal household activities. Five conversations for each NNS were tape-recorded (audio only) during a 10-week period between their 7th and 16th week in Finland. Although the period was relatively short, it fell within a critical phase when the NNS-informants were attending an intensive basic course in Finnish, twenty 45-minute lessons each week. The course had started 5 weeks before the period of the study and, as is usual, in addition to the use of everyday vocabulary and phrases, the learners were receiving instruction in inflecting nouns and verbs.

At first the NNSs were able to tell some basic facts about themselves and discuss a few familiar topics of an elementary level only, while in the final conversations they could express their opinions to a degree, give simple descriptions and produce short narratives in a fairly fluent and comprehensible manner. This obvious progress in their speaking abilities was reflected in their mean length of turns (MLT). During the period studied, the MLTs increased from 2.2 to 4.0 words for one and from 2.6 to 3.6 words for the other NNS informant. The NS apparently adapted her own speech in response to her interlocutors, since her MLTs concurrently increased from 2.5 to 3.2 or 3.3 words.

Outside the classroom, the NNSs had very few contacts with NSs, and the opportunity to take part in the conversations recorded for the present study was thus a new dimension of Finnish language use for them both. In their own opinion these conversational sessions also had a beneficial effect on their language learning. Because of the lack of NS contacts it is quite apparent, however, that it is the intensiveness of their formal instruction that mainly explains the remarkable increase in their MLTs and speaking abilities. 
A qualitative microanalysis was applied to the data, which were transcribed by following the CHILDES/CHAT-format (MacWhinney 2000). Negotiations of meaning were then extracted for closer microanalysis. They were defined on a functional basis as such sequences of conversation in which interlocutors have difficulty in understanding each other, and, in which they accordingly attempt to reach satisfactory agreement on what was said. The model of negotiations of meaning presented by Varonis and Gass (1985) appeared to function as a useful basis when developing the framework for the closer analysis: the obligatory moves included in their model are here referred to as a trouble source, a trouble signal and a response. In contrast to the conventions frequently applied in the field, these moves, or turns, were not classified by following a group of pre-set formal criteria. Instead, certain dialogical principles established by conversation analysts and thoroughly discussed by Linell (1993) were taken as a starting point. The actual interpretations made by the interlocutors in the situation, which are revealed by their verbal behaviour, have been used as a basis for identifying and analysing the various components of negotiations.

Although there were no attempts by the NS to consciously elicit negotiations of meaning, their average frequency was once a minute. This frequency was nearly identical in all conversations. This means that in each 30-minute sample there were some 30 negotiations of varying lengths, and, 17-26\% of all turns were included in negotiation sequences. There were no significant differences in the number of negotiations caused by NS versus NNSs utterances.

After exploring the general structure of negotiations of meaning, their linguistic features were analysed in more detail in order to find out how the forms were modified to reach shared meanings. The modifications performed when repeating or recasting the trouble source were described as either phonological (including phonetic changes), morphological, syntactic or lexical. The findings that will be discussed in the sections that follow mainly focus on the modifications performed and not the structure of negotiations. The main tendencies are illustrated with examples representing a much larger sample of corresponding data. Special attention will be paid to the morphological level, which in Finnish language data plays a central role but has not gained attention before. For this reason, some features of the Finnish linguistic system will be briefly introduced below. 


\section{The Finnish language as a learning target}

Finnish is a Finno-Ugric language, which is closely related to Estonian, and a more distant relative of Hungarian. There are about 5 million native speakers of the language. In recent decades Finnish has become a second language for about 100000 immigrants. In addition, most members of the Swedish-speaking minority in Finland (c. 300000 persons) use Finnish as a second language.

Among linguists, Finnish is known especially for its extensive morphology. At least in principle, each Finnish noun has about 2200 different inflective forms while each verb has 12000 . These numbers do not even include any derivatives (Karlsson 1983; see also Martin 1995). Most forms are relatively rare in colloquial speech, however, and it is obvious that complex morphology is likely to be avoided in NS-NNS interaction. Even with these restrictions, the learning task that Vietnamese immigrants encounter when arriving in Finland is highly challenging. They have a language with no inflection at all as their first language. Thus what they are faced with is bridging the gap between two languages that represent the opposite ends of a typological continuum.

Although Vietnamese immigrants can be expected to have particular problems in coming to terms with the Finnish linguistic system, it should be noted that whatever the first language of the learner, morphology is usually seen as the highest barrier. A natural consequence is that in the fields of both L2 teaching and research on Finnish it plays a central role as well (Martin 1995). Moreover, the interplay between phonology, morphology and syntax is rather demanding to learn, but this will not manifest itself to a great extent in the examples below. Thus only certain basic features of the Finnish morphological and inflectional system will be briefly described to make excerpts from the data clearer and more comprehensible for readers who have no knowledge of Finnish.

There are 15 cases in Finnish. In the examples below only some are central. The nominative case is considered the basic form. The partitive has several functions, the most important of which is to express indefinite quantity. Also important are certain local cases, such as the inessive and the illative, which will be translated in the examples by using such English prepositions as in, to etc.

In Finnish nominals, such elements as the plural marker or case suffixes are added to the word-stem: tammikuu 'January'-tammikuussa 'in January' (inessive, the suffix is -ssa). In some words there are changes 
in the stem in different cases, as can be observed by comparing the basic form (nominative) and the inflected form (inessive, the suffix is -ssa): puhelin 'telephone' - puhelimessa 'on the phone'.

Some cases, such as the illative, for example, have several alternative suffixes, depending on the type of the stem: Ruotsi 'Sweden'-Ruotsiin 'to Sweden'; työ 'work (noun)' - työhön 'to work'.

When suffixes are added, various sound alternations may take place in the stem. They sometimes radically change the word and it is a real challenge for a NNS then to recognize the basic form or a familiar stem behind it. An example that will be discussed in the following section (Example 7) is the pair työhön 'to work, singular illative' and töihin 'to work, plural illative'; the latter cannot easily be recognized as an inflected form of työ 'work' since the first vowel of the diphthong in the stem has been deleted when adding the plural marker $i$.

Inflecting verbs follows similar principles. The finite verbs occurring in the excerpts are very simple, since they only include markers of person and tense: ajatella 'to think'; ajattelen 'I think' - ajattelet 'you think'; ajattelin 'I thought' - ajattelit 'you thought'. Thus, $n$ marks the first person singular and $t$ the second person singular, and $i$ functions as a past tense marker.

It is essential to note when reading the following sections that the Finnish case suffixes and other morphological elements are crucial parts of the word. For instance, it is not a convention among native speakers to leave them out in interaction when repeating the word they belong to, in contrast to prepositions and articles in English. The translation of examples thus easily disguises the point, which makes it essential to examine the original Finnish expressions and their form as well. Finnish is written almost phonemically, so practically there is a $1: 1$ correspondence between sounds and letters. The IPA equivalents for Finnish $y, \ddot{a}$ and $\ddot{o}$ are $[y],[æ]$ and [œ], and double letters indicate long sounds.

The following two sections will provide data on the development of linguistic modifications performed by both interlocutors in negotiations of meaning. I will first discuss some examples where the trouble source is produced by the NNS, and then others in which it is produced by the NS.

\section{NNS utterance as a trouble source}

When signalling trouble in understanding a NNS utterance, the NS usually repeats it as a whole, or a part of it, but not identically. While 
repeating, she also makes a guess or a suggestion as to which form and meaning the NNS might be trying to express, and by recasting like this she 'translates' the utterance from the learner language into target-like Finnish, attempting to make it more comprehensible. In the first conversations she often modifies the phonetic or phonological features of the utterances, but also pays attention to some morphological deficiencies as well. This can be seen in the first example.

(1) NNS: minä haluan menee ää \# ruossi. I want go erm \# 'ruossi'.

NS: ruotsiin?

to Sweden?

NNS: joo.

yeah.

The NS suggests here a small phonological change $s s>t s$ to make the word ruossi sound more comprehensible, and adds the illative suffix -in when repeating the problematic item. The NNS seems to accept the interpretation. He simply says yeah, and by doing so he quits the negotiation. No incorporation of the inflected form thus occurs.

The next two interrelated excerpts (Examples 2 and 3) include both phonological and morphological modifications. The NNS apparently mispronounces the word myyjä 'a salesperson' when telling about his friend: the long vowel is produced as a diphtong. By recasting, the NS suggests the change $y \ddot{o}>y y$, and a short-term incorporation of this phonological modification immediately takes place on the NNS side.

(2) NNS: joo hän myö \# hän myöjä. yeah she 'myö' \# she 'myöjä'

NS: myyjä? a salesperson?

NNS: joo \# hän myyjä. yeah \# she salesperson.

(3) NNS: hän myö \# paita she 'myö' \# shirt.

NS: vaatteita. clothes.

NNS: vanha paita. old shirt.

NS: vanhoja paitoja? old shirts?

NNS: joo vanha paita hän kauppa yeah old shirt she shop nimi on... name is...

A lexical and then a morphological modification by NS follows when the interlocutors attempt to reach agreement about what is being sold. The NNS uses the word paita, 'shirt' which the NS interprets to refer to clothes in general. She thus suggests the noun vaate 'an item of clothing' in plural partitive form vaatteita 'clothes', which the NNS obviously is not familiar with. Instead of accepting this suggestion, he expands his own previous 
expression by adding a qualifying word vanha 'old'. The inflection that the context would require is still missing, and when repeating this NNS utterance, the NS elaborates it by adding the plural markers (causing sound-alternation $a>o$ in the stem of both words) and the partitive suffixes. By doing this, she again modifies the NNS expression into a more intelligible form. In the following exchanges no incorporation of these morphological modifications occurs. Instead, all the nouns used by the NNS remain uninflected. The same thing happens very frequently in these conversations, since the NNSs continuously use both nouns and verbs without inflecting them, whereas the NS intuition seems to require inflecting in order to reach a more comprehensible and target-like form. Although the inflection is offered to the NNSs by their NS interlocutor, it is thus not yet entering their linguistic system. A satisfactory agreement on the meaning is quite obviously reached, however.

In the previous examples, it is the NS that takes the main responsibility for clarifying meanings, although the trouble source is located in a NNS utterance. Whenever possible, she forms a hypothesis for an intended meaning rather than forcing the NNS to elaborate or explain it. In these examples the modifications made by the NS first accumulate on the phonological and morphological levels, but the syntactic and lexical levels are not quite kept intact either. The NNSs repeat or even incorporate the reformulations offered in their own utterances as such, the only systematic exception being those modifications that deal with morphology. Inflectional elements simply do not become incorporated in their utterances yet.

Sometimes the problems of understanding are so severe, however, that the NS is not able to offer recasts, but resorts to open wh-questions or some indirect trouble signals such as hesitating, mumbling or lack of verbal response. In those instances the main responsibility is carried by the NNSs. However, the tendencies described above can be found in these instances as well. In the first conversations, the NNSs modify the phonological features or pronunciation only, whereas later it is the syntactic form of problematic utterances that gains more attention. There are no recognizable morphological elaborations to be observed in the responses formulated by the NNSs. This confirms in part the observation that morphology as yet plays no active role in their linguistic system.

The following two excerpts provide some evidence of the phenomenon. The first is the beginning of a lengthy negotiation which finally leads to the mutual understanding that throughout this sequence the 
NNS has been attempting to find out and pronounce the word kehua 'praise', in order to assure his interlocutor that the food he was serving was not praiseworthy. The phonetic modifications suggested are rather misleading, and understanding is later reached as soon as the NNS finds the notebook where he has written down the word. In this very elementary phase of language learning in their seventh week in Finland, the NNSs are obviously not ready to reformulate other linguistic levels and are thus forced to focus on the phonemic or phonetic features of their problematic utterances, however frustrating it may be.

(4) NNS: ei teva teiva. no 'teva' 'teiva'.

$\begin{array}{lll}\text { NS: } & \text { mitä? } & \text { what? } \\ \text { NNS: } & \text { ei teiva. } & \text { no 'teiva'. } \\ \text { NS: } & \text { ei? } & \text { no? } \\ \text { NNS: } & \text { teiva. } & \text { 'teiva'. } \\ \text { NS: } & \text { mitä se on? } & \text { what is it? } \\ \text { NNS: } & \text { teiva \# keva. } & \text { 'teiva' \# 'keva' } \\ \text { NS: } & \text { sano vielä. } & \text { say it again. }\end{array}$

Two weeks later the means the NNSs used for negotiating meaning apparently started to change. The topic of the conversation is precisely the same, and concerns tasting Vietnamese food, but here the ways in which the NNS explains and modifies the trouble source are much richer than in the example above.

(5) NNS jos ei maistu \# ei ei \# puhu minu if no taste \# no no \# talk about mi- minua.

me

NS: 0 .

$0 .(=$ no response $)$

NNS: joo maistu \# ei maistu.

yeah taste \# not tastes.

NNS: ymmatko?

NS: en.

you understand?

NNS: en?

no I don't.

NS: en.

no I don't?

no I don't.

NNS: jos minä teen ruokaa \# ei maistu. if I make food \# not tastes.

NS: joo. yeah.

NNS: joo. yeah.

NNS: ei \# ei sanoi kaikki minulle. not \# not said everything to me.

NS: ei saa sanoa? may not say?

NNS: joo \# minä ei sanoa. $\quad$ yeah \# I not to say. 
The NNS constructs a new syntactic environment for his key words, alters both words and word orders several times and also operates with such ambiguous morphological elements as the partitive suffix $a$ in ei puhu minua 'not talk about me' and the past tense marker $i$ in ei sanoi 'not said'. These are not target-like forms in the context, but almost in the end of the negotiation he manages to catch a correct morphological form minulle 'to me, illative' required by the verb 'to talk'. It is difficult to decide whether it is a prefabricated pattern acquired as such or a conscious and successful inflection, but it is employed in a target-like context, anyway. However, the fact that such inflected elements seldom appear in the NNS productions, might suggest the former interpretation to be more warranted.

As the examples reveal, the Vietnamese learners of Finnish receive a great deal of modified input in the negotiations caused by their own utterances, and they are also forced to modify their own output on various occasions. The linguistic levels at which modifications take place vary during the period under study according to the speaker (NS vs. NNS) and the stage in the NNS's process of language learning.

When it is the NS who suggests linguistic modifications by recasting, she operates first on the phonetic or phonological level but soon shifts her attention via morphology to syntax and lexicon. The NNSs follow a similar pathway with one remarkable difference, which is that they hardly ever modify the morphological features of their own troublesome utterances. This is in accordance with the way in which they react to the modifications suggested by their NS interlocutor. When morphological modifications are suggested, they are not incorporated by the NNSs in their following utterances, whereas the other types of restructuring are either accepted by positive feedback or even incorporated in further exchanges.

\section{NS utterance as a trouble source}

It is also the case that when the NNSs signal difficulty in comprehending NS utterances it is mostly the NS that actively offers various reformulations to eliminate the trouble. She is typically forced to do this in her response if the NNS trouble signal includes no suggestions for interpretation, as in the following example from the fourteenth week. Here the NS replaces the noun mustekalaa 'squid, partitive' by the corresponding referential pronoun sitä 'it, partitive' and also changes the word order 
to make her problematic question more conventional and comprehensible. The NNS is having his dinner which includes some squid, and this explains the use of the pronoun in this context.

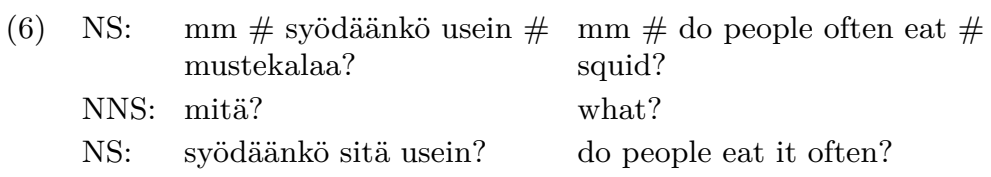

Both open wh-questions and minimal or indirect trouble signals such as hesitating $m m$ ? are rather infrequent among the trouble signals produced by the NNSs, however. They are strongly outnumbered by repetitions. A closer study of negotiations started by a NNS repetition also reveals an interesting systematicity and development that has not been noted before, and the examples that follow will thus focus on this type alone.

In the very first conversations in their seventh week in Finland, the NNSs repeat one word at a time to signal difficulty. Usually it is the last word of the utterance, and they repeat it as such, at least if they are able to. The NS regards such repetitions as requests for clarification and thus responds by making some linguistic modifications to her original utterance. She never says yeah only, as the NNSs usually do in a corresponding situation.
(7) NS: ja sitten sinä menet töihin. and then you go to work (pl. illative).

The native speaker here segments the problematic noun töihin 'to work, plural illative' by introducing the basic form työ 'work' first and then the singular equivalent for töihin, which obviously is supposed to be more salient and familiar to the NNS. She thus segments the problematic word and then inflects it again. By borrowing the English equivalent work the learner then shows that there is agreement on the meaning now and the need to negotiate is over.

In the first conversations the one who modifies by adding morphology or by segmenting inflected words is without exception the native speaker alone. In the next two conversations, in weeks nine and eleven, the situation starts to change, however. The NNSs seem to be experiencing a sort of morphological awakening. They are able to pay more and more attention to morphology when repeating NS utterances in negotiations. A sign 
of this is that they often delete suffixes when repeating the other's problematic nouns. In all three examples below, the NNS segments a noun in a successful way by extracting the basic form behind the inflected form.

(8) NS: ehkä tammikuussa maybe in January

NNS: tammikuu? January?

NS: $\mathrm{mm}$. $\mathrm{mm}$.

(9) NS: mitä sinä teet viikonloppuna? what are you doing in the weekend?

NNS: tämä viikonloppu? this weekend?

NS: $\mathrm{mm}$. $\mathrm{mm}$.

(10) NS: joo \# monessa talossa \# on sillon yeah \# in many houses \# there are kaksi kynttilää ikkunalla. two candles in the window then.

NNS: ikkuna?

NS: joo. yeah.

It might be expected that the inflected Finnish word would be repeated as a whole, and this is actually what native speakers of Finnish would do in a corresponding situation. In NS-NS interaction suffixes cannot be left out like this unlike English prepositions, for instance. Apparently the NNSs try to segment the problematic items somehow, which reveals that they must have a rather high metalinguistic awareness already: they are able to compare the inflected word encountered now with the basic form probably heard before, and they also have an intuition about where the stem ends and the ending starts.

Interestingly, the NS treats repetitions including correct segmenting as requests for confirmation and not clarification. She thus shows acceptance by responding with yeah or $\mathrm{mm}$ instead of starting to explain or segment what she said before. It is quite obvious that for the NS, the NNSs' ability to segment a word is intuitively a strong signal of really knowing the word - even irrespective of the NNSs' own perspective. For the NS, knowing a Finnish word thus includes recognizing its inflection as well. Apparently this is not the case for the NNSs for a long time.

The next example clearly shows that if the NNS does not know the word, he repeats it as it was, and if he knows it, he tries to isolate the basic form or stem. 
(11) NS: onko sinulla käynyt vieraita? have you had any guests?

NNS: vieraita? guests?

NS: mm. $\mathrm{mm}$.

NS: yst- ystäviä. fr- friends.

NNS: ystävä. friend.

NS: $\mathrm{mm}$. $\mathrm{mm}$.

The NNS is able neither to segment nor to recognize the word vieraita 'guests', but the substitutive noun ystäviä 'friends' the NS offers in her subsequent response appears to be much easier. The NNS immediately finds the familiar basic form ystävä 'friend' by leaving the plural marker and the partitive suffix out. Again, on the basis of successful segmentation, the NS makes an immediate inference that the NNS knows the word and the negotiation is over.

Sound alternations may sometimes make the task of segmenting even more complicated than it normally is. The basic form of vieraita would be vieras, for example. The final $s$ thus disappears when the plural marker $i$ is added. Later on, the NNSs learn to manage words that include these sound alternations. An example is the word puhelin 'telephone' which has the inessive form puhelimessa 'on the phone' where the stem is puhelimeand the suffix is -ssa. It is also worth noting that the NNS is now able to pick up problematic items from the middle of the flow of speech as well.

(12) NS: kumpaa sinä puhut useammin puhelimessa \# suomea vai vietnamia?

which do you speak on the phone more often \# Finnish

NNS: puhelin? or Vietnamese?

NS: niin. phone? yeah.

Usually it is a question of such frequent and familiar words as telephone, week or day, for example. This might suggest that the NNSs only want to make quite sure that they have recognized the lexical items correctly. However, they also start to segment items that are so strongly lexicalized that many native speakers could hardly deconstruct them, since the basic form is hypothetical by nature and hidden behind various sound alternations and changes in the stem. In other words, the NNSs are segmenting forms that NSs perceive as unitary or unsegmentable. This offers rather strong evidence for the interpretation that the NNSs consciously use segmenting as a tool that might help to find a familiar word or stem and thus promote understanding. 
In the following examples, the NNS is able to reconstruct the root of the word quite correctly, which is a most demanding task. There are several derivatives in Finnish that are related to these roots, but in clarifying the meaning of the NS utterance they unfortunately do not appear to be rather useful and thus function only as a starting point for negotiating.

(13) NS: onko teillä ollut kauan puhelin? have you had a phone for a long time? NNS: kauka? 'kauka'?

(14) NS: onko se tarpeeksi? is that enough?

NNS: tarve? a need?

The form kauka really is the linguistic root form of the derivative kauan 'for a long time' and also that of another rather frequent derivative kaukana 'far away', but it does not exist as an independent lexeme in Finnish. Segmenting the word tarpeeksi 'enough' leads to a correct root as well. As a result the NNS finds the form tarve 'a need', from which also such much more common words as tarvita 'to need' and tarpeellinen 'necessary' have been derived. It is very unlikely that the NNSs would encounter such rare forms as kauka or tarve without systematically inferring them, so these examples clearly illustrate their growing morphological awareness.

In the last two conversations in weeks fourteen and sixteen, the NNSs started to segment verbs too when repeating the other's utterances, and usually this is a question of tense. During this time past tense forms have not become well-established in the learners' own productions and they systematically employed present tense forms when talking about things that had already taken place.

The following two examples are from the fourteenth week. The topic introduced by the NS is the NNS's arrival in Finland. To make the problematic verb forms more comprehensible, the NNS changes the second person to first person and past tense to present tense.

(15) NS: mitä muuta sinä pelkäsit? what else were you afraid of?

NNS: pelkään? I am afraid of?

NS: $\quad$ pelkäsit \# kun sinä tulit \# you were afraid of \# when you came \# ensimmäisenä päivänä. the first day. 
(16) NS: mitä sinä ajattelit kun sinä näit sinun kodin?

NNS: ajattelen?

NS: niin.

NS: kun sinä tulit tuosta ovesta sisään ja näit \# täällä minä asun

NNS: joo.

NS: $\quad \mathrm{mm}$.

NNS: $\mathrm{mm}$.

NS: mitä sinä ajattelit? what did you think when you saw your home?

I think?

yeah.

when you came in through that door and saw \# this is where I'm going to live

yeah.

$\mathrm{mm}$.

$\mathrm{mm}$.

what did you think?

The NS does not accept this kind of misleading morphological modification straight away, since it does not reveal that the time-reference is clear for the NNS, although it shows that the word as such is familiar. The NS thus responds by repeating the past time reference, and tries to make it clear by mentioning again which situation she is talking about. When answering the questions, the NNS employs present tense forms, but he seems to be talking about the right situation, however. No incorporation of past tense thus occurs, although he seems to understand what he was asked.

Failure to incorporate the inflectional elements offered by the NS is a characteristic feature of the NNSs negotiating strategy. Although they notice inflective elements, they hardly ever make any attempts to incorporate the offered inflection in their subsequent utterances, although they do incorporate phonological, syntactic and lexical changes. Neither do they start elaborating the morphological features of their own utterances yet. During the period of the study the missing morphological markers are continuously added by the NS alone.

\section{Discussion}

The aim of the study was to discover how negotiations of meaning are mutually constructed in a NS-NNS conversation when the NNS informants are at the initial stage of learning Finnish as a L2, and to discover how linguistic material is treated by the interlocutors in order to make it more comprehensible.

Apart from phonology, syntax and lexicon, morphology was also a target of modification in negotiations of meaning. Morphological modifications have rarely been treated in previous studies (see Pica 1994; Pica 
et al. 2006; Deen 1997) and, as the results of the present study suggest, this is a consequence of the typological particularities of the languages that have been studied. In languages such as Finnish the inflective elements play such a crucial role that the comprehensibility of utterances often depends on them. A need to negotiate may thus occur also when the NS uses inflected forms that the NNS is not familiar with, or the NNS uses words without inflecting them appropriately. In the present study, the NNS informants had an isolating language as their first language, which partly explains the extent of the gap between their learner language and the target language system.

Contrary to expectations, quite consistent progress was evident in the linguistic behaviour of the interlocutors even within a period of ten weeks. At first the NS primarily modified the phonological and phonetic features of NNS utterances, shifting her attention thereafter via morphology to syntax and lexicon. When the source of trouble was in her own previous turn, the modifications basically followed the same pattern except that there was no need to tackle the phonetic or phonological features. Thus a certain kind of continuum was evident, with progression from the smallest linguistic elements to larger units, although there was naturally a lot of overlap rather than well-defined shifts between distinct phases.

In principle, the NNSs' target focus of concern changed in the same way during the period of the study. At first they paid most attention to their problems of pronunciation, but soon to syntactic and lexical deficiencies as well. However, lack of inflection in their own utterances hardly bothered them at all, and although the NS continuously offered various markers and suffixes to be added to the problematic items to make them more comprehensible and target-like, no incorporation of these elements occurred in the NNS utterances that followed. Other types of reformulations seemed to enter their linguistic system, but not inflection. Among the most striking features of NNS linguistic behaviour in negotiations was that although they did not operate with inflection productively in the negotiation sequences, they started to do so receptively by segmenting markers and suffixes belonging to the problematic expressions used by the NS.

Receptive segmenting of inflectional elements obviously serves the goal of understanding for NNSs in the same way as it does in first language acquisition (see Peters 1985). By segmenting, the NNSs thus attempt to recognize the lexical items hidden behind inflection. Interest- 
ingly enough, this is intuitively clear to the native interlocutor as well, since she treats the successfully segmented repetitions as requests for confirmation and not clarification. Successful segmenting thus implies to her that the words are being recognized and understood by the NNS. However, such segmenting would be exceptional and even unacceptable in NS-NS interaction, which confirms Kalin's (1995) observation that NSs are not actually "real natives" when conversing with NNSs. Instead, they follow partly different rules when interpreting the other's linguistic behaviour than in the case of NS-NS interaction.

Unfortunately, the data in the present study did not cover the productive phase when the NNSs indisputably start to inflect Finnish words in negotiation sequences. Even though the Finnish morphological system was intensively taught on the language course they were attending, it apparently remained a hazy area that was not available for productive use yet. However, as Peters (1985) has shown, receptive segmenting is a prerequisite for productive segmenting in first language acquisition, and this seems to apply to second language acquisition as well. This means that to learn to combine morphemes one has to know how to cut words into pieces. It would thus be too early to expect NNSs to use Finnish inflectional morphology productively before they have a command of receptive segmenting. Recognizing familiar words behind various stems, markers, endings and sound-alternations is a necessary first step to take.

The receptive segmenting performed by the NNSs shows that their awareness of the role and function of Finnish morphology develops gradually. In the negotiation sequences the NNSs are forced to pay attention to the existence and role of inflection, since the NS employs forms that they do not yet have in their own learner language. These inflected forms may appear in NS utterances that cause difficulty in understanding, as well as in signals of difficulty that give negative feedback on the comprehensibility of the NNSs' utterances. As a result, the NNSs are prompted to recognize that morphological cues are crucial in second language input and its comprehension.

\section{References}

Cameron, Judy - Frank W. Epling 1989. Successful problem solving as a function of interaction style for non-native students of English. In: Applied Linguistics 10: 392-406. 
Carpenter, Helen - K. Seon Jeon - David MacGregor - Alison Mackey 2006. Learners' interpretations of recasts. In: Studies in Second Language Acquisition 28:209 236.

Deen, Jeanine 1997. Dealing with problems in intercultural communication. A study of negotiation of meaning in native-nonnative speaker interaction (Studies in Multilingualism 5). Tilburg University Press, Tilburg.

Doughty, Catherine - Teresa Pica 1986. "Information gap" tasks: Do they facilitate second language acquisition? In: TESOL Quarterly $20: 305-25$.

Kaivapalu, Annekatrin 2005. Lähdekieli kielenoppimisen apuna [Contribution of L1 to foreign language acquisition]. University of Jyväskylä, Jyväskylä.

Kalin, Maija 1995. Coping with problems of understanding. Repair sequences in conversations between native and non-native speakers (Studia Philologica Jyväskyläensia 36). University of Jyväskylä, Jyväskylä.

Karlsson, Fred 1983. A Finnish grammar. WSOY, Porvoo.

Leeman, Jennifer 2003. Recasts and second language development: Beyond negative evidence. In: Studies in Second Language Acquisition 25:37-63.

Linell, Per 1993. Troubles with mutualities: Towards a dialogical theory of misunderstanding and miscommunication (Arbetsrapporter fran Tema K 1993, 2). University of Linköping, Linköping.

Long, Michael 1983. Native speaker/non-native speaker conversation and the negotiation of comprehensible input. In: Applied Linguistics 4:126-41.

Long, Michael 1996. The role of the linguistic environment in second language acquisition. In: William C. Ritchie-Tej K. Bhatia (eds): Handbook of language acquisition, vol 2: Second language acquisition, 413-78. Academic Press, San Diego CA.

MacWhinney, Brian 2000. The CHILDES project: Tools for analyzing talk, vol. 1: Transcription format and programs, vol. 2: The database. Lawrence Erlbaum, Mahwah NJ.

Martin, Maisa 1995. The map and the rope: Finnish nominal inflection as a learning target Studia Philologica Jyväskylaensia 38. University of Jyväskylä, Jyväskylä.

Peters, Ann 1985. Language segmentation: Operating principles for the analysis and perception of language. In: Dan Isaac Slobin (ed.): The crosslinguistic study of language acquisition, 1029-67. Erlbaum, Hillsdale NJ.

Philip, Jenefer 2003. Constraints on "noticing the gap": Nonnative speakers' noticing of recasts in NS-NNS interaction. In: Studies in Second Language Acquisition $25: 99-126$

Pica, Teresa 1994. Review article. Research on negotiation: What does it reveal about second-language learning conditions, processes, and outcomes? In: Language Learning $44: 493-527$.

Pica, Teresa - Ruth Kanagy - John Falodun 1993. Choosing and using communication tasks for second language instruction and research. In: Graham Crookes Susan M. Gass (eds): Tasks and language learning: Integrating theory and practice, 9-34. Multilingual Matters, Clevedon. 
Pica, Teresa - Hyun-Sook Kang - Shannon Sauro 2006. Information gap tasks: Their multiple roles and contributions to interaction research methodology. In: Studies in Second Language Acquisition 28:301-38.

Pälli, Pekka - Sirkku Latomaa 1997. Aikuisten maahanmuuttajien suomen kielen taito [The Finnish language skills of adult immigrants]. Board of Education, Helsinki.

Rulon, K.- J. McCreary 1986. Negotiation of content: Teacher-fronted and smallgroup interaction. In: Richard R. Day (ed.): Talking to learn, 182-289. Newbury House, Rowley MA.

Suni, Minna 1996. Maahanmuuttajaoppilaiden suomen kielen taito peruskoulun päättövaiheessa [The Finnish language skills of immigrants in the end of the comprehensive school]. Board of Education, Helsinki.

Swain, Merrill 1985. Communicative competence: Some roles of comprehensible input and comprehensible output in its development. In: Susan M. Gass-Carolyn G. Madden (eds): Input in second language acquisition, 235-53. Newbury House Publishers, Cambridge.

Swain, Merrill 2005. The output hypothesis: Theory and research. In: Eli Hinkel (ed.): Handbook on research in second language teaching and learning, 471-84. Lawrence Erlbaum, Mahwah NJ.

Tarnanen, Mirja - Minna Suni 2005. Maahanmuuttajien kieliympäristö ja kielitaito [The linguistic environment and language skills of immigrants]. In: Paananen Seppo-Kirsti Pohjanpää (eds): Maahanmuuttajien elämää Suomessa [Immigrant lives in Finland], 9-21. Statistics Finland, Helsinki.

Varonis, Evangeline Marlos - Susan Gass 1985. Non-native/non-native conversations: A model for negotiations of meaning. In: Applied Linguistics $6: 71-90$.

Yule, Georg - Doris Macdonald 1990. Resolving referential conflicts in L2 interaction: The effect of proficiency and interactive role. In: Language Learning $40: 539-53$. 